\title{
Safety monitoring of treatment in bipolar disorder in a tertiary care setting in Sri Lanka and recommendations for improved monitoring in resource limited settings
}

Uthpali Mannapperuma ${ }^{1 *}$, Priyadarshani Galappatthy', Raveendra Laal Jayakody', Jayan Mendis², Varuni Asanka de Silva ${ }^{3}$ and Raveen Hanwella ${ }^{3}$

\begin{abstract}
Background: Safety monitoring of medicines is essential during therapy for bipolar disorder (BD). We determined the extent of safety monitoring performed according to the International Society for Bipolar Disorders (ISBD) guidelines in patients with BD attending the main tertiary care psychiatry clinics in Sri Lanka to give realistic recommendations for safety monitoring in resource limited settings.

Methods: Patients diagnosed with BD on mood stabilizer medications for more than 1 year were recruited. Data were collected retrospectively from clinic and patient held records and compared with the standards of care recommended by ISBD guidelines for safety monitoring of medicines.

Results: Out of 256 patients diagnosed with BD, 164 (64.1\%) were on lithium. Only 75 (45.7\%) had serum lithium measurements done in the past 6 months and 96 (58.5\%) had concentrations recorded at least once in the past year. Blood urea or creatinine was measured in the last 6 months only in 30 (18.3\%). Serum electrolytes and thyroid-stimulating hormone (TSH) concentrations were measured in the last year only in 34 (20.7\%) and 30 (18.3\%) respectively. Calcium concentrations were not recorded in any patient. None of the patients on sodium valproate $(n=119)$ or carbamazepine $(n=6)$ had blood levels recorded to establish therapeutic concentrations. Atypical antipsychotics were prescribed for 151 (59\%), but only 13 (8.6\%) had lipid profiles and only 31 (20.5\%) had blood glucose concentration measured annually. Comorbidities experienced by patients influenced monitoring more than the medicines used. Patients with diabetes, hypothyroidism and hypercholesterolemia were more likely to get monitored for fasting blood glucose and $(p<0.001)$, TSH $(p<0.001)$ and lipid profiles $(p<0.001)$. Lithium therapy was associated with TSH monitoring $(p<0.05)$. Therapy with atypical antipsychotics was not associated with fasting blood glucose or lipid profile monitoring $(p>0.05)$. A limitation of the study is that although some tests were performed, the results may not have been recorded.

Conclusions: Safety monitoring in BD was suboptimal compared to the ISBD guidelines. ISBD standards are difficult to achieve in resource limited settings due to a multitude of reasons. Realistic monitoring benchmarks and recommendations are proposed for methods to improve monitoring in resource limited settings based on our experience.
\end{abstract}

Keywords: Bipolar disorder, ISBD, Safety monitoring, Clinical audit

\footnotetext{
* Correspondence: uthpali.m@pharm.cmb.ac.lk

${ }^{1}$ Department of Pharmacology and Pharmacy, Faculty of Medicine, University

of Colombo, P.O.Box 271, Kynsey Road, Colombo 8, Sri Lanka

Full list of author information is available at the end of the article
}

(c) The Author(s). 2019 Open Access This article is distributed under the terms of the Creative Commons Attribution 4.0 International License (http://creativecommons.org/licenses/by/4.0/), which permits unrestricted use, distribution, and reproduction in any medium, provided you give appropriate credit to the original author(s) and the source, provide a link to the Creative Commons license, and indicate if changes were made. The Creative Commons Public Domain Dedication waiver (http://creativecommons.org/publicdomain/zero/1.0/) applies to the data made available in this article, unless otherwise stated. 


\section{Background}

Long term maintenance treatment for bipolar disorder (BD) consists of using lithium, other mood stabilizers, antipsychotics and antidepressants [1]. Patients often require lifelong treatment to mitigate negative outcomes of the disease and to prevent relapses, hospitalization, functional impairment and suicide [2].

Safety monitoring is an essential component of therapy in BD and recommendations are given by several organizations such as the International Society for Bipolar Disorders (ISBD) [3], Canadian Network for Mood and Anxiety Treatments (CANMAT) and National Institute for Clinical Excellence (NICE), in the United Kingdom $[1,4,5]$. These recommendations come from highincome countries and even these countries sometimes have difficulty in meeting these recommendations given [6]. Therefore, more realistic targets without compromising patient care is needed, considering costs of monitoring and availability of human and other resources particularly for resource limited settings [7-10].

Those on lithium therapy require regular therapeutic drug monitoring as lithium has a narrow therapeutic index. Such monitoring minimizes lithium toxicity and can be used to assess adherence to medication [11]. Long-term treatment with lithium is associated with occurrence of renal side effects such as chronic kidney disease and renal failure. The renal side effects of lithium were evident both from clinical studies having small numbers of subjects and from large scale epidemiological studies [12-17]. Apart from the renal side effects, metabolic and cardiovascular effects are also described particularly with newer antipsychotics that are used in patients with BD $[7,10,18]$. These effects are associated with the prescribed medications as well as other factors $[1,18-21]$.

Clinical audits and descriptive studies are carried out to assess whether the quality of care provided to patients is in keeping with the recommended standards and guidelines [9]. The ISBD commissioned a working group to develop guidelines for safety monitoring in $\mathrm{BD}$. The main objective of the guidelines was to recommend cost effective safety monitoring, highlight the preventable medication induced side effects and to facilitate the implementation of safety monitoring as a standard component of patient management. The guidelines provide an algorithm for baseline and continued treatment monitoring [3]. Whether these guidelines can be applied in different health care settings with limited resources needs to be evaluated in assessing quality of care offered to patients with $\mathrm{BD}$ in different settings.

Although lithium and other medicines have been in use for several decades, there is lack of information concerning treatment practices and monitoring of patients with $\mathrm{BD}$ in resource limited settings. In this background our study was planned with the objective of studying the adherence to safety monitoring recommendations among patients with $\mathrm{BD}$ attending the main tertiary care psychiatry referral clinics in the National Hospital of Sri Lanka (NHSL) in Colombo. In addition, this study also aimed to evaluate the performance of ISBD guidelines in resource limited settings and develop realistic monitoring recommendations for these settings along with strategies for implementing them. Since the ISBD criteria focus on the management of $\mathrm{BD}$ and emphasize on cost effective monitoring that could be applied in our local setting, recommendations given in ISBD guidelines were selected for this study.

\section{Methods}

This study was done in all 12 specialized psychiatry follow up clinics conducted in the main tertiary care referral hospital, the NHSL, during a 2 year period from 2013 to 2015. These clinics are conducted by 4 consultants attached to the University of Colombo Psychiatry Unit and 8 consultants of the National Institute of Mental Health (NIMH), the only specialized psychiatry hospital in Sri Lanka. The target was to include a minimum of 30 consecutive patients with BD from each clinic into the study to obtain a representative sample of patients managed by all clinics in the NHSL psychiatry clinics. Ethical clearance for this study was granted by the Ethics Review Committee of the Faculty of Medicine, University of Colombo, Sri Lanka.

Monitoring of medications according to the ISBD safety monitoring recommendations was assessed, by recording the type of medication, monitoring tests and the frequency of testing. The tests considered and the recommended frequency of testing for each drug was done according to ISBD guidelines [3].

\section{Inclusion/exclusion criteria}

Patients with a clinical diagnosis of BD diagnosed as per ICD-10 criteria who were on treatment for more than 1 year were considered eligible. Patients or guardians not giving written informed consent and those with other psychiatric diagnoses such as schizophrenia, unipolar depression, anxiety states and obsessive compulsive disorder were excluded. Demographic and clinical data, and laboratory test results were obtained from the clinic records and patient held records.

\section{Assessments}

Patient records were retrieved and the diagnosis of each patient was confirmed before assessing the safety monitoring criteria. The recorded safety monitoring data for each test performed in every patient recruited was compared with the recommendations of the ISBD criteria pertaining to laboratory tests given in the guidelines. 


\section{Outcomes}

The percentage of patients having the tests performed at the recommended time intervals was the main outcome measure evaluated. Percentage of tests performed was compared with the studies reported from other settings. Reasons for poor monitoring were noted. Realistic safety monitoring recommendations were proposed for resource limited settings considering the existing practice, facilities and resources available.

\section{Statistical analysis}

Percentages of patients having the tests done at the recommended time period were calculated. Associations of performing lab testing with medications used or comorbidities were determined using the chi-square test. Association of lithium measurement with mood control was also assessed. A $p$ value of $<0.05$ was considered as significant.

\section{Results}

\section{Characteristics of the sample}

Altogether 256 consecutive patients were included in the analysis. Although the target was to include 30 consecutive patients from each clinic, in some clinics this number was not achieved, as the number of patients followed up in the clinics meeting inclusion/exclusion criteria were less than 30 during the study period.

Medications used in patients with BD and characteristics and other information about the patients recorded are given in Table 1 . The commonest mood stabilizer used was lithium carbonate in 164 (64.1\%), followed by sodium valproate in 119 (46.5\%). There were 151 (59\%) patients with $\mathrm{BD}$ on atypical antipsychotics.

\section{Monitoring of patients on lithium}

The monitoring tests done and the frequency of monitoring of the patients for different medications is summarized in Table 2.

Of the 164 patients on lithium, only 75 patients (45.7\%) had a serum lithium measurement done in the past 6 months. Lithium concentrations were recorded in the past year also only in 96 (58.5\%). Average testing frequency was 0.67 tests per patient per year. Considering the tests done during 6 months and 1 year, testing frequency of lithium was once in every 13-18 months. Renal function (urea or creatinine) was available or recorded only in 39 (23.8\%) during a 1 year period.

Of the patients having a serum lithium estimation done in the past year, there were 5 patients with serum lithium concentrations less than $0.4 \mathrm{mmol} / \mathrm{L}$ recorded and 2 patients having serum lithium measurements recorded above $1 \mathrm{mmol} / \mathrm{L}$. A patient with $0.4 \mathrm{mmol} / \mathrm{L}$ serum lithium concentration had 2 tests done in the past year and one patient with a concentration above 1
Table 1 Characteristics of the patients

\begin{tabular}{|c|c|}
\hline Characteristics & Number \\
\hline Number of patients, $\mathrm{n}$ & 256 \\
\hline Gender, Male & $137(53.5 \%)$ \\
\hline Age, years, mean (SD) & $45.55(12.41)$ \\
\hline Age range, years & $18-73$ \\
\hline \multicolumn{2}{|l|}{ Marital Status } \\
\hline Married & $179(69.9 \%)$ \\
\hline Unmarried & $65(25.4 \%)$ \\
\hline Separated & $10(3.9 \%)$ \\
\hline Widow & $2(0.8 \%)$ \\
\hline \multicolumn{2}{|l|}{ Educational level } \\
\hline Below grade 5 & $15(5.9 \%)$ \\
\hline Between grade 5 and $\mathrm{O} / \mathrm{L}$ & $53(20.7 \%)$ \\
\hline Education uptoO/L examination & $119(46.5 \%)$ \\
\hline Education upto $\mathrm{A} / \mathrm{L}$ examination & $55(21.5 \%)$ \\
\hline Graduate & $10(3.9 \%)$ \\
\hline Other & $4(1.6 \%)$ \\
\hline \multicolumn{2}{|l|}{ Income level } \\
\hline no steady income & $120(46.9 \%)$ \\
\hline has steady income & $136(53.1 \%)$ \\
\hline \multicolumn{2}{|c|}{ Patients with an exacerbation of illness in the past year } \\
\hline No exacerbations & $136(53.1 \%)$ \\
\hline Having one or more episodes & $112(43.8 \%)$ \\
\hline Missing data & $8(3.1 \%)$ \\
\hline Duration on medicines, years, mean (SD) & $13.17(10.22)$ \\
\hline \multicolumn{2}{|l|}{ Therapy } \\
\hline Lithium & $164(64.1 \%)$ \\
\hline Sodium valproate & $118(46.1 \%)$ \\
\hline Carbamazepine & $6(2.3 \%)$ \\
\hline Atypical antipsychotics & 151 (59\%). \\
\hline Olanzepine & $90(35.2 \%)$ \\
\hline Risperidone & $54(21.1 \%)$ \\
\hline Quetiapine & $9(3.5 \%)$ \\
\hline Typical antipsychotics & $37(14.5 \%)$ \\
\hline Haloperidol & $30(11.7 \%)$ \\
\hline Chlorpromazine & $5(2 \%)$ \\
\hline Antidepressants & $50(19.5 \%)$ \\
\hline Fluoxetine & $26(10.2 \%)$ \\
\hline Imipramine & $12(4.7 \%)$ \\
\hline \multicolumn{2}{|l|}{ Co-morbidities identified } \\
\hline Diabetes mellitus & $59(23.0 \%)$ \\
\hline Hypothyroidism & $28(10.9 \%)$ \\
\hline Hypertension & $41(16.0 \%)$ \\
\hline Hypercholestrolaemia & $36(14.1 \%)$ \\
\hline
\end{tabular}

O/L Ordinary Level, $A / L$ Advanced level, SD Standard Deviation 
Table 2 Monitoring tests done and frequency of monitoring recorded for different medications

\begin{tabular}{|c|c|c|c|c|}
\hline Monitoring investigation & $\begin{array}{l}\text { Lithium testing percentage at } 6 \text { months, } \\
1 \text { year and testing frequency }(n=164)\end{array}$ & Carbamazepine $(n=6)$ & $\begin{array}{l}\text { Valproate } \\
(n=119)\end{array}$ & $\begin{array}{l}\text { Newer antipsychotics } \\
(n=151)\end{array}$ \\
\hline \multirow{3}{*}{$\begin{array}{l}\text { Serum drug } \\
\text { concentration }\end{array}$} & $75(45.7 \%)$ in last 6 months & \multirow[t]{3}{*}{ ND } & \multirow[t]{3}{*}{ ND } & \multirow[t]{3}{*}{ NR } \\
\hline & $96(58.5 \%)$ in the last year & & & \\
\hline & Frequency - once in 13 months & & & \\
\hline \multirow[t]{3}{*}{ Serum Creatinine/ urea } & $30(18.3 \%)$ in the last 6 months & \multirow[t]{3}{*}{1 record in the last year } & \multirow[t]{3}{*}{ NR } & \multirow[t]{3}{*}{ NR } \\
\hline & $39(23.8 \%)$ in the last year & & & \\
\hline & Frequency - once in 33 months & & & \\
\hline Full Blood Count (FBC) & NR & 1 record in the last year & $9(7.6 \%)$ in the last year & NR \\
\hline \multirow[t]{2}{*}{ Electrolytes } & $34(20.7 \%)$ in the last year & \multirow[t]{2}{*}{1 record in the last year } & \multirow[t]{2}{*}{ NR } & \multirow[t]{2}{*}{ NR } \\
\hline & Frequency - once in 5 years & & & \\
\hline \multirow[t]{2}{*}{ TSH } & $30(18.3 \%)$ in the last year & \multirow[t]{2}{*}{ NR } & \multirow[t]{2}{*}{ NR } & \multirow[t]{2}{*}{ NR } \\
\hline & Frequency - once in $51 / 2$ years & & & \\
\hline Serum Calcium & ND & NR & NR & NR \\
\hline Liver function tests & NR & ND & $19(16 \%)$ in the last year & NR \\
\hline Fasting blood glucose & NR & NR & $23(19.3 \%)$ in the last year & $31(20.5 \%)$ in the last year \\
\hline Fasting lipid profile & NR & NR & $14(11.8 \%)$ in the last year & $13(8.6 \%)$ in the last year \\
\hline
\end{tabular}

NR Not required, ND Not done

$\mathrm{mmol} / \mathrm{L}$ also had two tests done in the past year. The average serum lithium concentration for the patients with any serum lithium measurement was $0.67 \mathrm{mmol} / \mathrm{L}$.

The creatinine levels were available or recorded during the last 6 months only in $30(18.3 \%)$ patients giving a testing frequency of once in every 33 months (nearly 3 years). Thirty (18.3\%) patients had Thyroid Stimulating Hormone (TSH) concentrations recorded during the past year giving a testing frequency of about once every $51 / 2$ years. Serum calcium concentrations were not done in any patient.

\section{Monitoring of patients on valproate and carbamazepine} Among the patients, 119 were on sodium valproate and6 patients were on carbamazepine. None of these patients had therapeutic blood levels recorded to establish therapeutic concentrations.

Among patients receiving sodium valproate, liver functions tests were recorded only in $19(16 \%)$ in the past year. Full blood count was recorded only in 9 (7.6\%) patients while only 23 (19.3\%) had fasting blood glucose records.

Patients receiving carbamazepine therapy did not have liver enzymes tested. One patient each had full blood count, electrolyte testing and serum creatinine records.

\section{Monitoring of patients on atypical antipsychotics}

Of the 151 patients on atypical antipsychotics only 13 (8.6\%) had a lipid profile measurement done in the past year giving a testing frequency of once in every 12 years. Fasting blood glucose was also measured only in 31
(20.5\%) giving a testing frequency of once in every 5 years.

\section{Association of monitoring with patient characteristics and medication}

On statistical analysis of associations of testing with medications used and comorbidities, the patient comorbidities such diabetes or hypothyroidism influenced patient monitoring rather than therapy with medications such as lithium or atypical antipsychotics (Table 3).

\section{Discussion}

Monitoring of patients is an essential component of treating BD to ensure medication safety, adherence to therapy and adequate control of the disease [11]. In this study, which assessed the safety monitoring of patients with $\mathrm{BD}$, the lithium concentrations were measured in the past 6 months in less than half of patients and in one-year in 59\%. The minimum lithium testing frequency was once in 13 months. Of the patients having any serum lithium recorded there were few patients with serum lithium concentrations beyond the recommended therapeutic serum lithium concentrations. The average concentration of the serum lithium concentrations recorded was $0.67 \mathrm{mmol} / \mathrm{L}$ indicating that the patients who do serum lithium monitoring are also the patients achieving therapeutic serum lithium concentrations. Having poor mood control was not associated with patients having serum lithium concentration recorded, as a similar proportion of patients with good mood control and poor mood control had serum lithium estimations at $37 \%$ for the good mood control group and $38.4 \%$ for 
Table 3 Associations of comorbidities/medications with monitoring tests

\begin{tabular}{lll}
\hline Factor or medication used & Monitoring & $p$ \\
\hline Diabetes & Fasting blood glucose test in the last year & $<.001$ \\
Hypothyroidism & TSH testing in the past year & $<.001$ \\
Hypercholesterolemia & Lipid profile testing in the past year & $<.001$ \\
Lithium & TSH testing in the past year & $<0.05$ \\
Lithium & Serum urea or creatinine testing in the past year \\
Having a disease exacerbation in the past year & Lithium monitoring in the past year \\
Valproate & Liver function tested in the past year \\
Atypical antipsychotics & Fasting blood glucose test in the last year \\
Atypical antipsychotics & Lipid profile testing past year & $>0.05$ \\
\hline
\end{tabular}

the poor mood control group. One reason for this may be the prolonged duration the patients were on treatment. For patients on lithium therapy for a long period of time, regular serum lithium concentration monitoring may not be considered necessary by the care providers, which could have contributed to lower rates of testing.

The findings of our study and similar studies done are summarized in Table 4. Our data are comparable with a veterans community study coming from the USA [7] where only $19 \%$ of patients had repeat lithium tests done at an interval of 6 months or less and a study from Brazil where only 7 of the 36 patients sampled (19\%) had a lithium measurement done in the past year [8]. However our results fall short of data coming from the United Kingdom (UK) where 96\% have had at least one test and $80 \%$ having 2 to 5 tests done during the preceding year.
Yet, even in the UK study, $4 \%$ have had no lithium testing done at all [6].

Considering the capacity of a resource limited clinic setting and possibility of some tests done being not recorded, with no electronic data monitoring, our finding of lithium monitoring of $45 \%$ in 6 months and average testing frequency every 13 months could be considered as acceptable. However, we should strive to have lithium level tested at least once in 6 months as serum lithium estimation is a low cost test which is done free of charge in Sri Lanka through the hospital laboratories for patients followed up in the clinics. These patients need to get an appointment and visit the laboratory to give blood. This test costs US Dollars (USD) 3.50-5.50 in the private sector laboratories. Considering all these factors at least one lithium estimation in 6 months in at least

Table 4 Comparison of safety monitoring tests done in the present study with previously reported studies in different settings

\begin{tabular}{|c|c|c|c|c|c|c|}
\hline \multirow[t]{2}{*}{ Therapy } & \multirow[t]{2}{*}{ Test } & \multirow{2}{*}{$\begin{array}{l}\text { Sri Lanka present study } \\
(2014-15)\end{array}$} & \multicolumn{2}{|c|}{ UK (2008-10), (Paton et al., 2013) } & \multirow{2}{*}{$\begin{array}{l}\text { USA 2004-06 } \\
\text { (Kilbourne et al., 2007) }\end{array}$} & \multirow{2}{*}{$\begin{array}{l}\text { Brazil } 2009 \\
\text { (Souza et al., 2013) }\end{array}$} \\
\hline & & & 2008 & 2010 & & \\
\hline \multirow[t]{3}{*}{ Lithium } & $\begin{array}{l}\text { Serum } \\
\text { lithium }\end{array}$ & $\begin{array}{l}58.5 \% \text { (past year) } \\
45.7 \% \text { (past } 6 \text { months) }\end{array}$ & $90 \%$ ( $1-4$ tests in an year) & $96 \%$ (1-4 tests in 1 year) & 19\% (past 6 months) & 19\% (past year) \\
\hline & TFT & 18.3\% (Past year) & $82 \%$ ( $1-2$ tests per year) & $92 \%$ ( $1-2$ tests per year) & 39\% (past 6 months) & Not studied \\
\hline & $\begin{array}{l}U C \\
\text { and } E\end{array}$ & $\begin{array}{l}\text { 23.8\%: Urea and } \\
\text { Creatinine } \\
\text { 20.7\%: Electrolytes } \\
\text { (Past year) }\end{array}$ & $\begin{array}{l}81 \% \\
(1-2 \text { or more testsper year) }\end{array}$ & $\begin{array}{l}90 \% \\
(1-2 \text { or more tests per year })\end{array}$ & $83 \%$ (past 6 months) & Not studied \\
\hline \multirow{3}{*}{$\begin{array}{l}\text { Sodium } \\
\text { valproate }\end{array}$} & TDM & No records & Not studied & Not studied & $56 \%$ (past 6 months) & Not studied \\
\hline & $\mathrm{FBC}$ & $7.6 \%$ (past year) & Not studied & Not studied & $72 \%$ (past 6 months) & Not studied \\
\hline & LFT & $16 \%$ (past year) & Not studied & Not studied & $76 \%$ (past 6 months) & Not studied \\
\hline \multirow[t]{2}{*}{ Carbamazepine } & TDM & No records & Not studied & Not studied & $42.9 \%$ (past 6 months) & Not studied \\
\hline & $\mathrm{FBC}$ & $\begin{array}{l}1 \text { record in the } \\
\text { past year }\end{array}$ & Not studied & Not studied & $72 \%$ (past 6 months) & Not studied \\
\hline \multirow{2}{*}{$\begin{array}{l}\text { Atypical } \\
\text { antipsychotics }\end{array}$} & FBG & $20.5 \%$ (past year) & Not studied & Not studied & 69\% (past 6 months) & Not studied \\
\hline & $\begin{array}{l}\text { Lipid } \\
\text { profile }\end{array}$ & $8.6 \%$ (past year) & Not studied & Not studied & $50 \%$ (past 6 months) & Not studied \\
\hline
\end{tabular}


Table 5 Monitoring criteria used as per ISBD guidelines and our recommendations (Ng et al., 2009)

\begin{tabular}{|c|c|c|c|}
\hline Drug & Monitoring factor & $\begin{array}{l}\text { Time interval } \\
\text { recommended by the ISBD }\end{array}$ & Our recommendations \\
\hline \multirow[t]{2}{*}{ Lithium } & $\begin{array}{l}\text { Serum lithium, Electrolytes, } \\
\text { Urea and Creatinine }\end{array}$ & Every 3-6 months & $\begin{array}{l}\text { At least every } 6 \text { months in } 80 \% \text { patients } \\
\text { for serum lithium and } 70 \% \text { for other tests }\end{array}$ \\
\hline & $\begin{array}{l}\text { Calcium and Thyroid } \\
\text { Stimulating Hormone }\end{array}$ & Annually & Annually for majority of patients \\
\hline \multirow[t]{2}{*}{ Sodium valproate } & $\begin{array}{l}\text { Full blood count and Liver } \\
\text { Function Tests }\end{array}$ & Annually & Annually for majority \\
\hline & $\begin{array}{l}\text { Therapeutic drug monitoring } \\
\text { of sodium valproate, Fasting } \\
\text { blood glucose and Lipid Profile }\end{array}$ & When clinically indicated & When clinically indicated \\
\hline \multirow[t]{2}{*}{ Carbamazepine } & $\begin{array}{l}\text { Full blood count, Liver Function Tests, } \\
\text { Electrolytes, Urea and Creatinine }\end{array}$ & Annually & Annually for majority \\
\hline & $\begin{array}{l}\text { Therapeutic drug monitoring of } \\
\text { carbamazepine }\end{array}$ & When clinically indicated & When clinically indicated \\
\hline $\begin{array}{l}\text { Atypical antipsychotics e.g.: } \\
\text { Olanzapine, Risperidone, Quetiapine }\end{array}$ & $\begin{array}{l}\text { Fasting blood glucose and fasting } \\
\text { lipid profile }\end{array}$ & Annually & Annually for majority \\
\hline
\end{tabular}

$80 \%$ of patients is suggested as a realistic target for our setting (Table 5).

The ISBD guidelines recommend blood urea, serum creatinine and electrolytes (renal function tests) to be measured at 3 to 6 month intervals. In our study only 30 (18.3\%) patients had serum creatinine measured at 6 months and testing frequency was once in every 3 years. Electrolyte measurement was also poor with only 34 (20.7\%) having it done at least once during the last year. An audit done in the USA by Kilborne et. al. reports of patients on lithium having serum creatinine and/or urea done at a rate of $83 \%$ at 6 month intervals [7]. In the UK the renal function tests were done in $70 \%$ patients at 6 month intervals [6]. Compared to the ISBD recommendations, our testing is quite low, especially considering the reported decline of renal function in patients on lithium therapy [17]. In Sri Lanka, testing serum creatinine and serum electrolytes is done free of charge through hospital laboratories and costs about USD 3 and 7 respectively in the private sector. It could be recommended to request both these tests at 6 monthly intervals every time when serum lithium is requested, to achieve a target of $70 \%$ monitoring for resource limited settings. Having boxes to be ticked for serum creatinine and electrolytes when serum lithium is tested would avoid the need for separate filling of request forms.

Our reported data on TSH measurement in only $18.3 \%$ in 1 year and frequency of once in $5 \frac{1}{2}$ years falls far short of what is done in other countries. A US study reports 39\% testing during the past 6 months. Data coming from the UK show a testing rate of $66 \%$ at 6 month intervals and $92 \%$ at 1 year [6]. TSH is an expensive test in our setting if done in the private sector (approximately USD 7), but it is done free of charge in government hospitals. Measuring TSH at least annually in most patients could be recommended as a realistic target in resource limited settings.

None of the patients on lithium therapy in this study had serum calcium concentrations measured. According to ISBD recommendations, serum calcium measurement in patients with bipolar disorder is necessary as long term lithium therapy is known to cause hypercalcemia [3]. The ISBD guidelines recommend annual testing. Therefore we suggest serum calcium monitoring at least once a year in our study setting since this test is also available free of charge from hospital laboratories.

The patients who were on valproate and carbamazepine did not undergo therapeutic drug monitoring because facilities were not available through the hospitals in our study setting. The liver enzymes were also not done in any of the patients on carbamazepine while $16 \%$ of patients on valproate had liver enzymes performed. In a study done in the USA, 75\% of patients on both drugs had liver function tests done [7]. In our study testing of full blood counts was also done only in $7.6 \%$ patients on valproate and on one patient on carbamazepine. In the study from USA the rate was approximately $72 \%$ for both drugs (Table 4). Although the ISBD guidelines recommend annual fasting blood glucose monitoring for patients on valproate, in our study only 19.3\% had it done. Similarly renal function had been done only on a single patient on carbamazepine whereas the ISBD recommendation is to test annually. Although the monitoring of all tests were unsatisfactory we recommend annual testing for liver enzymes, full blood counts, and fasting glucose for patients on sodium valproate and carbamazepine as all these are low cost tests readily available in our setting and can be done easily 
with education of medical staff caring for the patients and implementation and monitoring of quality improvement programs. Therefore, more training and inputs to medical staff managing these patients is needed emphasizing the importance of these tests for monitoring.

For patients on atypical antipsychotics, the monitoring of fasting blood glucose and cholesterol levels is poor where only $20.5 \%$ had fasting blood glucose and only $8.6 \%$ had lipid profile monitoring. These levels are below the monitoring done in the USA where 69 and $50 \%$ patients had fasting blood glucose and lipid profile monitored respectively [7]. However findings of our study are comparable to some other studies done on patients taking antipsychotics. In a baseline audit done in the UK in 2006, plasma glucose and lipid profiles were measured in only 28 and $22 \%$ of patients respectively [10]. Subsequently an audit based quality improvement programme improved the monitoring of metabolic outcomes in patients taking antipsychotics. By the year 2012 the screening of blood glucose and lipid profile had doubled to 52 and 50\% respectively [10]. Measuring blood glucose and lipid profiles annually and achieving monitoring in the majority of patients could be recommended as a realistic target initially in resource limited settings.

Results of our study indicate that for long-term treatment of patients on bipolar disorder, the services provided in the study setting fall below the standards demonstrated in countries such as the UK and the USA. Reasons for such lower rates of monitoring include the difficulty in implementing recommendations in the overcrowded clinics and lack of quality improvement programs and monitoring of such programs, rather than the non-availability of tests or the costs of testing. Clinical audits and monitoring of the treatment practices do not occur regularly and audit based quality improvement processes are lacking. However with establishment of healthcare quality and safety units in all major hospitals in the Ministry of Health, it is possible to implement changes with commitment of the staff. In the present psychiatric care setting, patients' unwillingness to get the tests done would also have contributed to the lower rates. If a system is in place for regular reminders and prompting by the clinicians, a higher rate of monitoring could be achieved.

All safety monitoring tests are done free of charge in the study setting but our results indicate poor monitoring of patients. This indicates that the system in our setting is capable of providing the necessary resources to fulfill the recommended requirements of safety monitoring but patient factors and provider factors have contributed to the poor safety monitoring practices.
The safety monitoring practices and recommendations need to be modified according to the requirements, socio-cultural factors and economic conditions where the psychiatric care is provided. The guidelines recommended need to use realistic monitoring rates which could ultimately lead to better outcomes for the patients.

Quality improvement programs and clinical audits to measure performance are required to assess the situation, followed by feedback and actions taken to improve the monitoring of therapy. These should pave way for improving current practice. Several strategies were identified towards achieving this as given in Table 6.

In the UK, Mental Health Trusts are required to implement national guidelines and Care Quality Commission measures adherence. General Practitioners receive financial incentives when targets are met [22]. Such incentives and continuous feedback has demonstrated the improvement of monitoring of patients on lithium in the UK [6]. The audit based quality improvement programme in the UK is also an example of improvement of safety monitoring practices based on audits [10]. The quality improvement programme for patients having BD conducted a baseline audit followed up by supplementary audits. The supplementary audits revealed an increase of the proportion of patients having four serum lithium tests over the previous year from 30 to $48 \%$, monitoring at least two tests of renal function per year from 55 to $70 \%$ and two thyroid function testing from 49 to $66 \%$ [6]. In a resource limited setting, individual commitment, feedback and incentives can lead to better outcomes to patients. A repeat study is needed in the current setting to assess impact of any interventions and the recommendations provided in this study.

Some of the clinics handled approximately 200 patients during a 6 hour period served by only 6 to 7 doctors. The low rate of recording the tests is partly due to the heavy work load. Some tests may have been performed although not recorded in clinic records. This is a limitation common to any audit, which uses recorded data. In the clinic settings no electronic data bases were maintained. There have been times during retrospective data collection, where some of the test services such as serum lithium monitoring were not available in the NHSL due to machine break down, which may have reduced the lithium testing frequency. Our sample is confined to the tertiary care referral setting in the main hospital in the capital city of the country, which has more facilities and health staff. Thus it is possible that the findings may not represent levels of monitoring in smaller units and clinics in peripheral areas of the country and may not be extrapolated to other settings. 
Table 6 Recommendation for testing, timing intervals, physician and institutional level actions for optimal safety monitoring in resource limited settings

\begin{tabular}{|c|c|c|}
\hline Drug & Physician level actions & Institutional level actions \\
\hline \multirow[t]{2}{*}{ Lithium } & $\begin{array}{l}\text { 1. Request Serum lithium, electrolytes, and creatinine } \\
\text { at least every } 6 \text { months } \\
\text { 2. Educate patients on the importance of safety monitoring } \\
\text { with blood test to overcome patient based barriers } \\
\text { 3. Conduct clinical audits for safety monitoring } \\
\text { 4. Request serum calcium and TSH annually } \\
\text { 5. Record all tests done in patient held records }\end{array}$ & $\begin{array}{l}\text { 1. Have one form for requesting serum lithium with tick } \\
\text { boxes for electrolytes, and creatinine } \\
\text { 2. Ensure availability of serum lithium testing facilities at } \\
\text { all times } \\
\text { 3. Promote conducting clinical audits for safety monitoring } \\
\text { and implement audit based quality improvement } \\
\text { programmes through Healthcare quality and safety units } \\
\text { of hospitals. } \\
\text { 4. Make arrangements to give dates for blood testing from } \\
\text { the clinics eliminating the need to come another day to get } \\
\text { a test date }\end{array}$ \\
\hline & & $\begin{array}{l}\text { 5. Ensure availability of serum Calcium and TSH testing } \\
\text { facilities at all times }\end{array}$ \\
\hline \multirow[t]{2}{*}{ Sodium valproate } & $\begin{array}{l}\text { 1. Request full blood count, liver enzymes (AST/ALT) } \\
\text { at baseline and annually }\end{array}$ & $\begin{array}{l}\text { 1. Training and continuous professional development } \\
\text { activities for medical staff on the need for safety } \\
\text { monitoring for alternative mood stabilizers. }\end{array}$ \\
\hline & $\begin{array}{l}\text { 2. Request therapeutic drug monitoring (TDM) of sodium } \\
\text { valproate, fasting glucose and lipid profiles at initiation of } \\
\text { therapy and when clinically indicated } \\
\text { 3. Record all tests done in patient held records }\end{array}$ & $\begin{array}{l}\text { 2. Establish TDM facilities for sodium valproate in } \\
\text { government sector and inform availability to clinics }\end{array}$ \\
\hline \multirow[t]{2}{*}{ Carbamazepine } & $\begin{array}{l}\text { 1. Request full blood count, liver enzymes (AST/ALT), } \\
\text { electrolytes, and creatinine annually }\end{array}$ & $\begin{array}{l}\text { 1. Training and Continuous Professional Development (CPD) } \\
\text { activities for medical staff on the need for safety monitoring } \\
\text { for alternative mood stabilizers }\end{array}$ \\
\hline & $\begin{array}{l}\text { 2. TDM of carbamazepine at initiation of therapy and } \\
\text { when clinically indicated } \\
\text { 3. Record all tests done in patient held records }\end{array}$ & $\begin{array}{l}\text { 2. Establish TDM facilities for carbamazepine in government } \\
\text { sector and inform availability to clinics }\end{array}$ \\
\hline $\begin{array}{l}\text { Atypical } \\
\text { antipsychotics e.g.: Olanzapine, } \\
\text { Risperidone, Quetiapine }\end{array}$ & $\begin{array}{l}\text { 1. Request fasting blood glucose and fasting lipid } \\
\text { profile annually } \\
\text { 2. Record all tests done in patient held records }\end{array}$ & $\begin{array}{l}\text { 1. Training and CPD activities for medical staff on the need } \\
\text { for safety monitoring for newer antipsychotics } \\
\text { 2. Establish facilities for lipid profile testing in the } \\
\text { government sector }\end{array}$ \\
\hline
\end{tabular}

\section{Conclusions}

Safety monitoring of patients with BD as per the ISBD guidelines is suboptimal in our resource limited setting. Monitoring of lithium concentration is better compared to the other tests. Monitoring of valproate and carbamazepine was non-existent and the metabolic safety screening for all patients was poor. The poor rates of monitoring are mostly due to organizational factors rather than lack of resources. Realistic benchmarks for targets to be achieved and recommendations for improved monitoring are suggested considering the problems in resource limited settings, with actions aiming at healthcare professionals and for institutions.

\footnotetext{
Abbreviations

BD: Bipolar Disorder; CPD: Continuous Professional Development; ISBD: International Society for Bipolar Disorders; NHSL: National Hospital of Sri Lanka; NIMH: National Institute of Mental Health; TDM: Therapeutic Drug Monitoring; TSH: Thyroid Stimulating Hormone; UK: United Kingdom; USA: United States of America; USD: United States Dollars
}

\section{Acknowledgments}

The authors would like to thank the patients who participated in this study and the consultant psychiatrists, doctors, nursing staff and the support staff at the psychiatry clinics of the NHSL who helped in this study.
Authors wish to thank the Research Writing Support Program (RWSP), Faculty of Medicine, University of Colombo, Sri Lanka, and Author AID at INASP for writing assistance.

\section{Authors' contributions}

PG and UM conceptualized the study, contributed to the study design, analysed the data and drafted the manuscript. UM carried out data collection. RLJ contributed to the study design, analysed the data and drafted the manuscript. JM, VA deS and RH participated in the design of the study and drafting the manuscript. All authors contributed to interpretation of results. All the authors read, revised and approved the final manuscript.

\section{Funding}

Uthpali Mannapperuma was funded by the University of Colombo Doctoral Research Grant number AP/03/2011/PG/12. The funding body did not play a role in the design of the study, collection, analysis, interpretation of data and in writing the manuscript.

\section{Availability of data and materials}

The data sets generated and analyzed during the current study are not available publicly as ethical clearance was not obtained to share data publicly. However the data is available with the corresponding author and the data are also available in the manuscript without identifying confidential patient information.

Ethics approval and consent to participate

Ethical clearance was obtained from the Ethics Review Committee of the Faculty of Medicine, University of Colombo (EC-12-81). Written informed consent was obtained from each patient prior to data collection. 


\section{Consent for publication}

Not applicable.

\section{Competing interests}

The authors declare that they have no competing interests.

\section{Author details}

'Department of Pharmacology and Pharmacy, Faculty of Medicine, University of Colombo, P.O.Box 271, Kynsey Road, Colombo 8, Sri Lanka. ${ }^{2}$ National Institute of Mental Health, Angoda, Sri Lanka. ${ }^{3}$ Department of Psychiatry, Faculty of Medicine, University of Colombo, Colombo 8, Sri Lanka.

Received: 4 October 2017 Accepted: 13 June 2019

Published online: 24 June 2019

\section{References}

1. Yatham LN, Kennedy SH, Parikh SV, Schaffer A, Beaulieu S, Alda M, O'Donovan C, MacQueen G, McIntyre RS, Sharma V, et al. Canadian network for mood and anxiety treatments (CANMAT) and International Society for Bipolar Disorders (ISBD) collaborative update of CANMAT guidelines for the management of patients with bipolar disorder: update 2013. Bipolar Disord. 2013;15(1):1-44

2. Duffy A. The early natural history of bipolar disorder: what we have learned from longitudinal high-risk research. Can J Psychiatr. 2010;55(8):477-85.

3. Ng F, Mammen OK, Wilting I, Sachs GS, Ferrier IN, Cassidy F, Beaulieu S, Yatham LN, Berk M. The International Society for Bipolar Disorders (ISBD) consensus guidelines for the safety monitoring of bipolar disorder treatments. Bipolar Disord. 2009;11(6):559-95.

4. Yatham LN, Kennedy SH, O'Donovan C, Parikh S, MacQueen G, McIntyre R, Sharma V, Silverstone P, Alda M, Baruch P. Canadian network for mood and anxiety treatments (CANMAT) guidelines for the management of patients with bipolar disorder: consensus and controversies. Bipolar Disord. 2005; 7(Suppl 3):5-69.

5. de Souza C. Bipolar disorder: assessment and management. Clinical guideline 185. 2018. [https://www.nice.org.uk/quidance/cg185/chapter/1Recommendations]. Accessed 20 June 2019

6. Paton C, Adroer R, Barnes TR. Monitoring lithium therapy: the impact of a quality improvement programme in the UK. Bipolar Disord. 2013;15(8): 865-75

7. Kilbourne AM, Post EP, Bauer MS, Zeber JE, Copeland LA, Good CB, Pincus $\mathrm{HA}$. Therapeutic drug and cardiovascular disease risk monitoring in patients with bipolar disorder. J Affect Disord. 2007:102(1):145-51.

8. Cd S, Vedana KGG, Mercedes BPC, Miasso Al. Bipolar disorder and medication: adherence, patients' knowledge and serum monitoring of lithium carbonate. Rev Lat Am Enfermagem. 2013;21(2):624-31.

9. Paton C, Barnes TRE. Undertaking clinical audit, with reference to a prescribing Observatory for Mental Health audit of lithium monitoring. Psychiatr Bull. 2014:38(3):128-31.

10. Barnes TRE, Bhatti SF, Adroer R, Paton C. Screening for the metabolic side effects of antipsychotic medication: findings of a 6-year quality improvement programme in the UK. BMJ Open. 2015;5(10).

11. Malhi GS, Tanious M, Bargh D, Das P, Berk M. Safe and effective use of lithium. Aust Prescr. 2013:36(1):18-21.

12. Presne C, Fakhouri F, Noël L-H, Stengel B, Even C, Kreis H, Mignon F, Grünfeld J-P. Lithium-induced nephropathy: rate of progression and prognostic factors. Kidney Int. 2003;64(2):585-92.

13. Bendz H, Schön S, Attman P-O, Aurell M. Renal failure occurs in chronic lithium treatment but is uncommon. Kidney Int. 2010;77(3):219-24.

14. Close H, Reilly J, Mason JM, Kripalani M, Wilson D, Main J, Hungin APS. Rena failure in lithium-treated bipolar disorder: a retrospective cohort study. PLOS One. 2014;9(3):e90169.

15. Rodrigo C, de Silva NL, Gunaratne R, Rajapakse S, De Silva VA, Hanwella R. Lower estimated glomerular filtration rates in patients on long term lithium: a comparative study and a meta-analysis of literature. BMC Psychiatry. 2014;14:1.

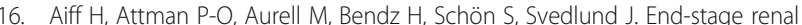
disease associated with prophylactic lithium treatment. Eur Neuropsychopharmacol. 2014;24(4):540-4

17. Shine B, McKnight RF, Leaver L, Geddes JR. Long-term effects of lithium on renal, thyroid, and parathyroid function: a retrospective analysis of laboratory data. Lancet. 2015;386(9992):461-8.
18. Correll CU, Detraux J, De Lepeleire J, De Hert M. Effects of antipsychotics, antidepressants and mood stabilizers on risk for physical diseases in people with schizophrenia, depression and bipolar disorder. World Psychiatry. 2015; 14(2):119-36.

19. Smith DJ, Martin D, McLean G, Langan J, Guthrie B, Mercer SW. Multimorbidity in bipolar disorder and undertreatment of cardiovascular disease: a cross sectional study. BMC Med. 2013;11(1):263.

20. Post RM, Altshuler LL, Leverich GS, Nolen WA, Kupka R, Grunze H, Frye MA Suppes T, McElroy SL, Keck PE Jr, et al. Illness progression as a function of independent and accumulating poor prognosis factors in outpatients with bipolar disorder in the United States. Prim Care Companion CNS Disord. 2014;16(6):10

21. Livingstone $\mathrm{C}$, Rampes $\mathrm{H}$. Lithium: a review of its metabolic adverse effects. J Psychopharmacol. 2006;20(3):347-55.

22. Collins N, Barnes TR, Shingleton-Smith A, Gerrett D, Paton C. Standards of lithium monitoring in mental health trusts in the UK. BMC Psychiatry. 2010;10:80

\section{Publisher's Note}

Springer Nature remains neutral with regard to jurisdictional claims in published maps and institutional affiliations.
Ready to submit your research? Choose BMC and benefit from:

- fast, convenient online submission

- thorough peer review by experienced researchers in your field

- rapid publication on acceptance

- support for research data, including large and complex data types

- gold Open Access which fosters wider collaboration and increased citations

- maximum visibility for your research: over $100 \mathrm{M}$ website views per year

At BMC, research is always in progress.

Learn more biomedcentral.com/submissions 